Article

\title{
Impact of Winter Snowfall on Vegetation Greenness in Central Asia
}

\author{
Farong Huang $1,2,3,4$, Ting Feng ${ }^{1,2,4,5}$, Zengkun Guo ${ }^{1,2,4}$ (D) and Lanhai Li $1,2,3,4,5, * \mathbb{D}$ \\ 1 State Key Laboratory of Desert and Oasis Ecology, Xinjiang Institute of Ecology and Geography, Chinese \\ Academy of Sciences, Urumqi 830011, China; huangfr@ms.xjb.ac.cn (F.H.); fengting18@mails.ucas.ac.cn (T.F.); \\ guozengkun18@mails.ucas.ac.cn (Z.G.) \\ 2 Ili Station for Watershed Ecosystem Research, Chinese Academy of Sciences, Xinyuan 835800, China \\ 3 Research Center for Ecology and Environment of Central Asia, Chinese Academy of Sciences, \\ Urumqi 830011, China \\ 4 Xinjiang Key Laboratory of Water Cycle and Utilization in Arid Zone, Urumqi 830011, China \\ 5 University of Chinese Academy of Sciences, Beijing 100049, China \\ * Correspondence: lilh@ms.xjb.ac.cn; Tel.: +86-991-782-3125
}

check for

updates

Citation: Huang, F.; Feng, T.; Guo, Z.; Li, L. Impact of Winter Snowfall on Vegetation Greenness in Central Asia. Remote Sens. 2021, 13, 4205. https:// doi.org/10.3390/rs13214205

Academic Editor: Conghe Song

Received: 20 August 2021

Accepted: 14 October 2021

Published: 20 October 2021

Publisher's Note: MDPI stays neutral with regard to jurisdictional claims in published maps and institutional affiliations.

Copyright: (C) 2021 by the authors Licensee MDPI, Basel, Switzerland. This article is an open access article distributed under the terms and conditions of the Creative Commons Attribution (CC BY) license (https:// creativecommons.org/licenses/by/ $4.0 /)$.

\begin{abstract}
Snowfall is an important climatic variable with remarkable impacts on vegetation greenness in the alpine and extra-tropical regions. Central Asia (CA) is located in the middle latitude with high mountains, and the ecosystem is vulnerable to climate change in CA. In this region, the vegetation response to winter snowfall and its interactions with growing season climatic factors on vegetation greenness is still unclear. Thus, this study attempted to examine the impact of winter snowfall on vegetation greenness with remote-sensing vegetation index and reanalysis climatic data, and to investigate the interactions between winter snowfall and growing season climatic factors and their influence on vegetation growth via path analysis. The results showed that there is a generally positive correlation between winter snowfall and vegetation greenness from May to September and during the whole growing season (April to September). This positive correlation was significant in $8 \%$ of the study area for the whole growing season. However, the increase in winter snowfall was not beneficial to the regional vegetation growth in April. The vegetation response to winter snowfall also relates to land-cover type and elevation. The vegetation greenness in grassland was depicted to be more sensitive to winter snowfall than that in forestland. The response turned from positive to negative when the elevation increased from below $3000 \mathrm{~m}$ to above $3000 \mathrm{~m}$. Moreover, the impact of winter snowfall on vegetation greenness was not regulated by temperature and precipitation in the growing season in more than $70 \%$ of CA. The impact relates to the interaction with April temperature in Central Kazakhstan, and is regulated by growing season precipitation in North Kazakhstan where annual precipitation mainly occurs in the growing season. The impact of winter snowfall on vegetation greenness is more important than growing season precipitation and temperature in some areas, since annual precipitation does not concentrate in the growing season or the relative increase of winter snowfall is great in these places. The results of the present study improve the understanding of vegetation response to climate change, and provide a scientific reference for environmental protection in $\mathrm{CA}$ and similar regions.
\end{abstract}

Keywords: vegetation greenness; snowfall; interaction; path analysis; Central Asia

\section{Introduction}

As a solid phase of precipitation, snowfall is a critical climate factor in middle and high latitudes, as well as in the mountainous area [1,2]. The snowfall varies with complex spatial and seasonal nature under climate change [3,4]. As the snowfall changes, there are variations of snow depth, snow cover area, and snow duration [5,6]. These variations, in turn, induce changes in the status of soil moisture and nutrients, which have impacted the physiological characteristics, community structure, and population dynamics 
of plants [7-9], as well as the vegetation phenology and greenness [10,11]. It is critical to investigate the relationship between snowfall and vegetation, which will be beneficial to understand the mechanisms between climate and ecosystem.

Currently, numerous researchers have examined the spatiotemporal variations of snowfall volume, the ratio of snowfall to the total precipitation, snowfall extremes, snowfall frequency, and snowfall concentration under global warming with multiple data sources, such as in situ observations, reanalysis data, and climate model datasets, as well as the influencing factors of these variations $[1-4,12,13]$. It was found that the snowfall changes vary with the study regions and periods. For example, extreme snowfall showed an insignificant decreasing trend in the Songhua River Basin of Northeastern China from 1960 to 2014 [4], while the snowfall extremes were projected to increase in the cool Rocky Mountains in the western United States in the mid-21st century [13]. The mechanism behind snowfall variations is complex. Temperature is the primary impact factor of snowfall variations. The relationship between temperature and snowfall varies from month to month and depends on a critical temperature threshold [14,15]. Specifically, the snowfall increases with temperatures below the critical temperature, while it decreases above this threshold. Furthermore, the snowfall is impacted by the teleconnection pattern (such as North Atlantic Oscillation), atmospheric water content, and local topography [1,3,4]. As snowfall is a critical part of the alpine and extra-tropical hydrological system [2], different researchers have examined the impact of snowfall on vegetation green-up date in the Qinghai-Tibetan Plateau with observed materials at stations [16], while few scholars have investigated the effect of snowfall on vegetation greenness in Northern Xinjiang of China, utilizing remote-sensing normalized-difference vegetation index (NDVI) products [17].

As a kind of data product widely used in regional vegetation research, remote sensing NDVI was also employed by numerous scholars to investigate the effect of precipitation, temperature, and snow on vegetation greenness and phenology in different parts of the world [18-22] due to its wide extent, temporal continuity, and low cost. For instance, based on the NDVI data generated by the Global Inventory Modelling and Mapping Studies (GIMMS), Wan [21] reported that there was not a significant correlation between the maximum vegetation greenness and snow duration/depth in the headwater regions in the Tibetan Plateau, while there was a significant positive correlation between snow duration and vegetation greenness in April and July. Considering the earth system composed of environmental factors with complex interactions [23], a few specialists have examined the regulation of temperature and precipitation on the effect of snow on vegetation dynamics by partial correlation [18], and the interaction of temperature and precipitation on vegetation greenness by path analysis [24]. According to the results reported by Yang et al. [17], the impact of winter snowfall on vegetation still existed in the growing season. However, research with much attention on the interactions between winter snowfall and growing season precipitation or temperature on the vegetation greenness is indeed still scarce.

Central Asia (CA), including Xinjiang in China and five countries of the former Soviet Union (i.e., Kazakhstan, Kyrgyzstan, Tajikistan, Turkmenistan, and Uzbekistan), is one of the largest arid regions in the world [25]. The region is characterized by a fragile ecosystem sensitive to climate change [26]. Under climate change, the annual average temperature and accumulated precipitation in CA have increased in recent decades [27,28], and the precipitation in winter has ascended significantly [29,30]. As it is cold in winter (average temperature $<-2{ }^{\circ} \mathrm{C}$ ) [31,32], most precipitation occurs as snowfall. This fact with the aforementioned implication on vegetation implies the crucial need to investigate the effect of winter snowfall on vegetation growth in CA under climate change. Prior researchers examined the vegetation dynamics and vegetation response to precipitation, temperature, and total water storage in the entirety of CA [30-34], as well as the impact of drought, human activities, vapor-pressure deficit, soil-moisture deficit, snow, and snowfall on vegetation greenness in different parts of CA [17,35-39]. Moreover, the spatial and temporal variations of snowfall volume, extreme, and concentration were analyzed in some areas of CA $[2,12,15,40,41]$. Nevertheless, neither the vegetation response to winter snowfall 
nor the interactions of winter snowfall, growing season precipitation, and temperature on vegetation greenness have been explored in the entirety of CA.

Owing to the drawbacks above, this study aimed to (1) analyze the response of vegetation greenness to winter snowfall, and (2) investigate the interactions between winter snowfall and growing season climatic factors on vegetation growth in CA. To achieve these two goals, the GIMMS NDVI and reanalysis snowfall data were used, and the path analysis method involving the interaction of variables was also employed. This work may provide useful information on the ecological construction of CA and arid regions.

\section{Data and Method}

\subsection{Study Area}

CA expands from $46^{\circ} 27^{\prime} \mathrm{E}$ to $96^{\circ} 26^{\prime} \mathrm{E}$ and $34^{\circ} 16^{\prime} \mathrm{N}$ to $55^{\circ} 31^{\prime} \mathrm{N}$ (Figure $1 \mathrm{a}$ ), with an area of $5.63 \times 10^{6} \mathrm{~km}^{2}$ [23]. Based on the $30 \mathrm{~m}$ spatial resolution digital elevation model (DEM) data from the US Geological Survey, the average elevation of CA is about $897 \mathrm{~m}$ (Figure 1b). The terrain is high in the east and low in the west, while the topography is complex with basins among mountains. The region is dominated by the continental climate with a large spatial difference of precipitation. The annual precipitation in the windward slope of mountains can reach up to $2000 \mathrm{~mm}$, while it is only $75-100 \mathrm{~mm}$ in the western desert [42]. Moreover, the annual precipitation in the eastern basin is less than $200 \mathrm{~mm}$ [43]. The annual average temperature is about $8^{\circ} \mathrm{C}$, and the temperature has shown a significant ascending trend in the last 30 years [24]. Based on the $300 \mathrm{~m}$ European Space Agency (ESA) Climate Change Initiative (CCI) land cover data in 2010 (Figure 1c, http:/ / maps.elie.ucl.ac.be/CCI/viewer/download.php (accessed on 20 August 2021)), the area percentage of grassland, cropland, forestland, and sparse vegetation is $26 \%, 14 \%, 4 \%$, and $51 \%$, respectively.

\subsection{Data}

Vegetation dynamics were analyzed with the third-generation NDVI product (NDVI3g.V1), with a 15-day temporal resolution and an 8-km spatial resolution (https: / / www.nasa.gov / nex (accessed on 20 August 2021)). The discontinuity caused by the different features of sensors for this dataset was homogenized with inter-calibration by sophisticated Bayesian methods [44]. This dataset has been used to investigate the seasonal and annual variations of vegetation greenness, and it was useful to study the relationship between climate change and vegetation dynamics at the regional and global scales [38,39,45]. The NDVI data from 1982 to 2015 were used in this study. The monthly NDVI was obtained with the Maximum Value Composition method to further reduce the residual atmospheric and bidirectional effects [46]. NDVI in the growing season was derived by averaging the monthly NDVI from April to September [47].

The regional precipitation, temperature, and snowfall data during 1982-2015 were collected from the global observed climatic dataset with a spatial resolution of 0.5 degrees and a temporal resolution of one day (https:/ / www.isimip.org/gettingstarted/inputdata-bias-correction/details/5/ (accessed on 20 August 2021)). This climatic dataset was constructed with the ERA-Interim reanalysis data, and has been corrected by elevation and observed monthly climate data $[48,49]$. The regional climate data were further interpolated to $8 \mathrm{~km}$ with the nearest resample method to match the spatial resolution of NDVI. The monthly precipitation, temperature, and snowfall were derived from the corresponding daily climatic data. The accumulated snowfall from December in the previous year to March was taken as the winter snowfall [50]. 
(a)


Figure 1. Geographical location in the world (a), elevation (b), and land cover (c) of Central Asia.

Before the regional monthly precipitation, temperature, and snowfall data were used to investigate the effect of climatic factors on vegetation, the accuracy of these data was evaluated using the observed data of stations with the area-weighted averaging method [51]. For this station-level comparison, values from grid boxes with centers within $8 \mathrm{~km}$ of the station were averaged. Considering the continuity of in-situ observations, the observed temperatures of 58 stations in CA (Figure $1 \mathrm{~b}$ ) were used (from the National Climatic Data Center (NCDC) of the U.S. National Oceanic and Atmospheric Administration (NOAA), ftp: / / ftp.ncdc.noaa.gov/pub/data/gsod/ (accessed on 20 August 2021)), as well as the observed precipitation of 50 stations (from China Meteorological Data Sharing Service 
System, http:/ / data.cma.cn/site/index.html (accessed on 20 August 2021)) and observed snowfall of 13 stations (from Annual Hydrological Report) in Xinjiang (Figure 1c). The comparisons between monthly reanalysis data and corresponding in-situ observations showed that the correlated coefficients between the reanalysis temperature and the observed one were larger than 0.98 in all stations and the whole study area (Figure 2a,b). The correlated coefficients between reanalysis precipitation and observed precipitation were significant at $1 \%$ level in most stations (Figure 2c). The reanalysis precipitation can explain $95 \%$ of observed precipitation temporal variation at the regional scale (Figure 2d), while the explanation of reanalysis snowfall was $89 \%$ (Figure 2e). Furthermore, the correlated coefficients between reanalysis and observed snowfall were significant at $5 \%$ level in all stations (Figure 2e). Therefore, the spatiotemporal variations of reanalysis temperature, precipitation, and snowfall proved to be consistent with the observed ones.

(a)

(c)
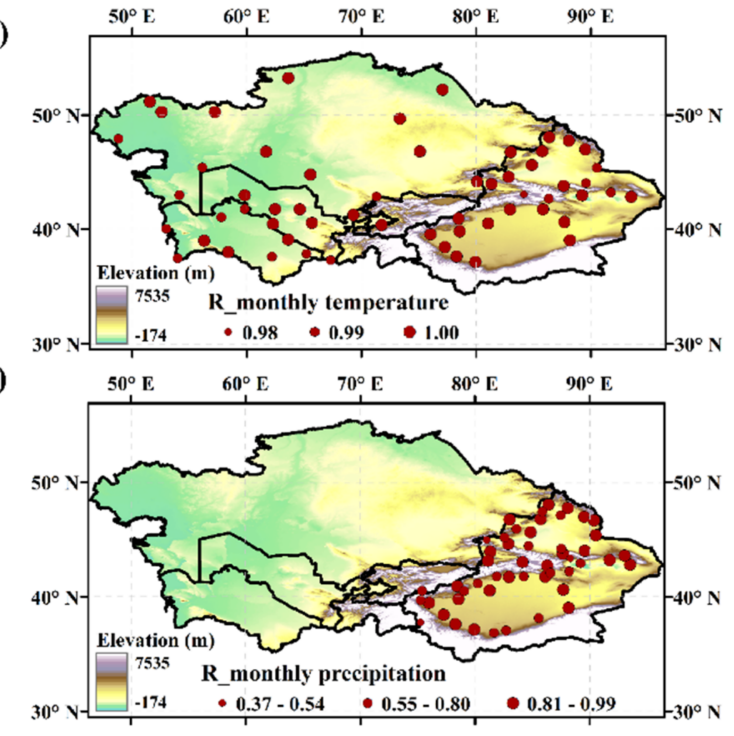

(e)

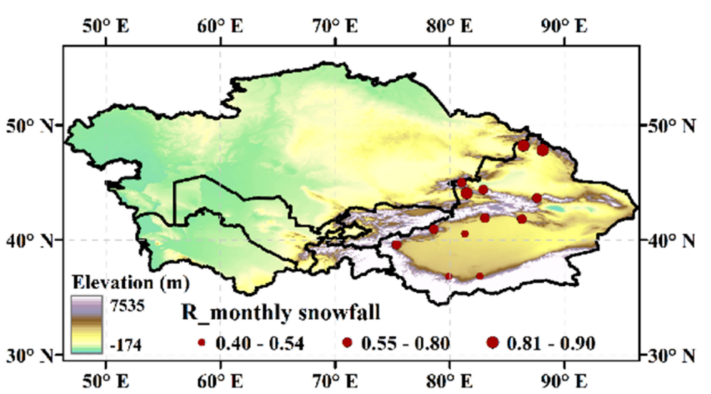

(b)

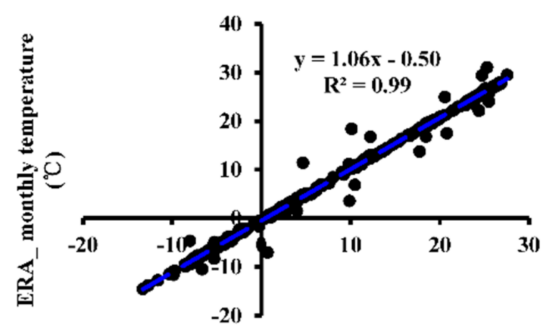

(d)

(f)
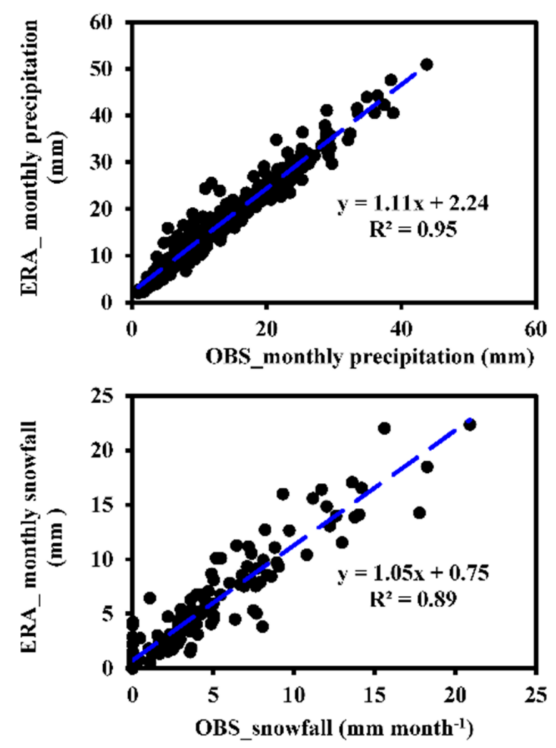

Figure 2. Determined coefficient $\left(\mathrm{R}^{2}\right)$ between ERA reanalysis data time series and the observed ones for monthly temperature $(\mathbf{a}, \mathbf{b})$, precipitation $(\mathbf{c}, \mathbf{d})$, and snowfall $(\mathbf{e}, \mathbf{f}) .(\mathbf{b}, \mathbf{d}, \mathbf{f})$ represent the averaged climatic variables of all stations.

To match the spatial resolution of NDVI, the land cover data were resampled to $8 \mathrm{~km}$ with the bilinear interpolation method, as well as the DEM data. The regional average NDVI, snowfall, precipitation, and temperature was acquired by calculating the average values for all grids in the study area except those of water body, snow and ice, and urban area. The average value for each land cover type was obtained by averaging the values at all grids of the corresponding land cover type.

\subsection{Method}

\subsubsection{Variation of Climatic Factors and NDVI}

Many researchers have combined Mann-Kendall (MK) test and Sen's slope ( $\beta$ ) to investigate the variation significance and magnitude of vegetation greenness and hydroclimatic variables [52-55]. In this work, we used the Sen's slope estimator $[56,57]$ to obtain 
the magnitude of change per year of snowfall and NDVI in 1982-2015. Based on Sen's slope $\beta, \beta>0$ represents an increasing trend, $\beta<0$ represents a decreasing trend, and the value of $\beta$ indicates the variation rate of the time series. Since this method lacks statistical significance testing for the variation trend, the MK test [58,59] was utilized to analyze the significance of the changing trend. Based on the absolute value of statistic $Z$ from the MK test, if $|Z|>1.96$, the trend is significant at the $5 \%$ level. According to $\beta$ and $|Z|$, the variations of snowfall and NDVI can be divided into five categories as shown below:

$$
\text { variation }=\left\{\begin{array}{cccc}
\text { increase } & \text { significantly } & \beta>0 & |Z|>1.96 \\
\text { decrease } & \text { significantly } & \beta<0 & |Z|>1.96 \\
\text { increase } & \beta>0 & |Z| \leq 1.96 \\
\text { decrease } & & \beta<0 & |Z| \leq 1.96 \\
\text { unobvious } & \text { else }
\end{array}\right\}
$$

\subsubsection{Effect of Winter Snowfall on Vegetation Growth}

Based on the path analysis [60], the total effect of winter snowfall on the growing season (i.e., from April to September) vegetation growth can be represented by the Pearson correlated coefficient $\left(r_{N D V I, S}\right)$ between growing season NDVI and winter snowfall. $r_{N D V I, S}$ can be decomposed into the direct effect of winter snowfall on growing season NDVI $\left(A_{S}\right)$, and the indirect effects of winter snowfall via growing season temperature $\left(A_{S T}\right)$ and precipitation $\left(A_{S P}\right)$ on growing season NDVI (Figure 3a), which can be expressed as:

$$
\begin{gathered}
r_{N D V I, S}=A_{S}+A_{S T}+A_{S P} \\
A_{S T}=r_{S T} \times A_{T} \\
A_{S P}=r_{S P} \times A_{P}
\end{gathered}
$$

where $r_{S T}\left(r_{S P}\right)$ is the person correlated coefficient between winter snowfall and growing season temperature (precipitation), and $A_{T}\left(A_{P}\right)$ is the direct path coefficient of growing season temperature (precipitation). Furthermore, $A_{S}, A_{T}$, and $A_{P}$ are the regression coefficients in the standardized multiple linear regression between the independent variables (i.e., winter snowfall, growing season precipitation, and temperature) and dependent variable (i.e., growing season NDVI). The significance of $A_{S}$ was examined by $\mathrm{F}$ test at 0.05 level. More details on the path analysis can be seen in the work of Huang et al. [22].

The Pearson correlated coefficient between monthly NDVI (April-September) and winter snowfall $\left(r m_{N D V I, S}\right)$ was used to represent the total effect of winter snowfall on monthly vegetation greenness. $r m_{N D V I, S}$ was also decomposed into the direct effect of winter snowfall on monthly NDVI $\left(A m_{S}\right)$ and the indirect effect of winter snowfall via temperature $\left(A m_{S T}\right)$ and precipitation $\left(A m_{S P}\right)$ on monthly NDVI (Figure $\left.3 \mathbf{b}\right)$ :

$$
\begin{gathered}
r m_{N D V I, S}=A m_{S}+A m_{S T}+A m_{S P} \\
A m_{S T}=r m_{S T} \times A m_{T}
\end{gathered}
$$

where $r m_{S T}$ denotes the Pearson correlated coefficient between winter snowfall and concurrent monthly temperature, and $A m_{T}$ is the direct path coefficient of concurrent month temperature. Considering the temporal lag of 1-3 months between precipitation and vegetation activities in most parts of CA [19], $A m_{S P}$ was defined as the sum of indirect effects via precipitation in the concurrent $\left(A m_{S P 0}\right)$ and previous 1-3 $\left(A m_{S P 1}, A m_{S P 2}, A m_{S P 3}\right)$ months:

$$
\begin{aligned}
A m_{S P}=A m_{S P 0}+A m_{S P 1}+A m_{S P 2}+A m_{S P 3} \\
A m_{S P 0}=r m_{S P 0} \times A m_{P 0} \\
A m_{S P 1}=r m_{S P 1} \times A m_{P 1} \\
A m_{S P 2}=r m_{S P 2} \times A m_{P 2}
\end{aligned}
$$




$$
A m_{S P 3}=r m_{S P 3} \times A m_{P 3}
$$

$r m_{S P 0}, r m_{S P 1}, r m_{S P 2}$, and $r m_{S P 3}$ are the Pearson correlated coefficients between winter snowfall and precipitation in the concurrent and previous 1-3 months, while $A m_{P 0}, A m_{P 1}$, $A m_{P 2}$, and $A m_{P 3}$ are the direct path coefficients of precipitation in the concurrent and previous 1-3 months. Additionally, $A m_{S}, A m_{T}, A m_{P 0}, A m_{P 1}, A m_{P 2}$, and $A m_{P 3}$ are the linear regression coefficients of winter snowfall, temperature in the concurrent month, and precipitation in the concurrent and previous 1-3 months in the standardized multiple-linear regression between these independent variables and the dependent variable of monthly NDVI. The significance of $A m_{S}$ was also examined by $\mathrm{F}$ test at 0.05 level. For April, May, and June, the indirect effects via precipitation in the previous 1-3, 2-3, and 3 months were not considered respectively, since these previous months are in winter.
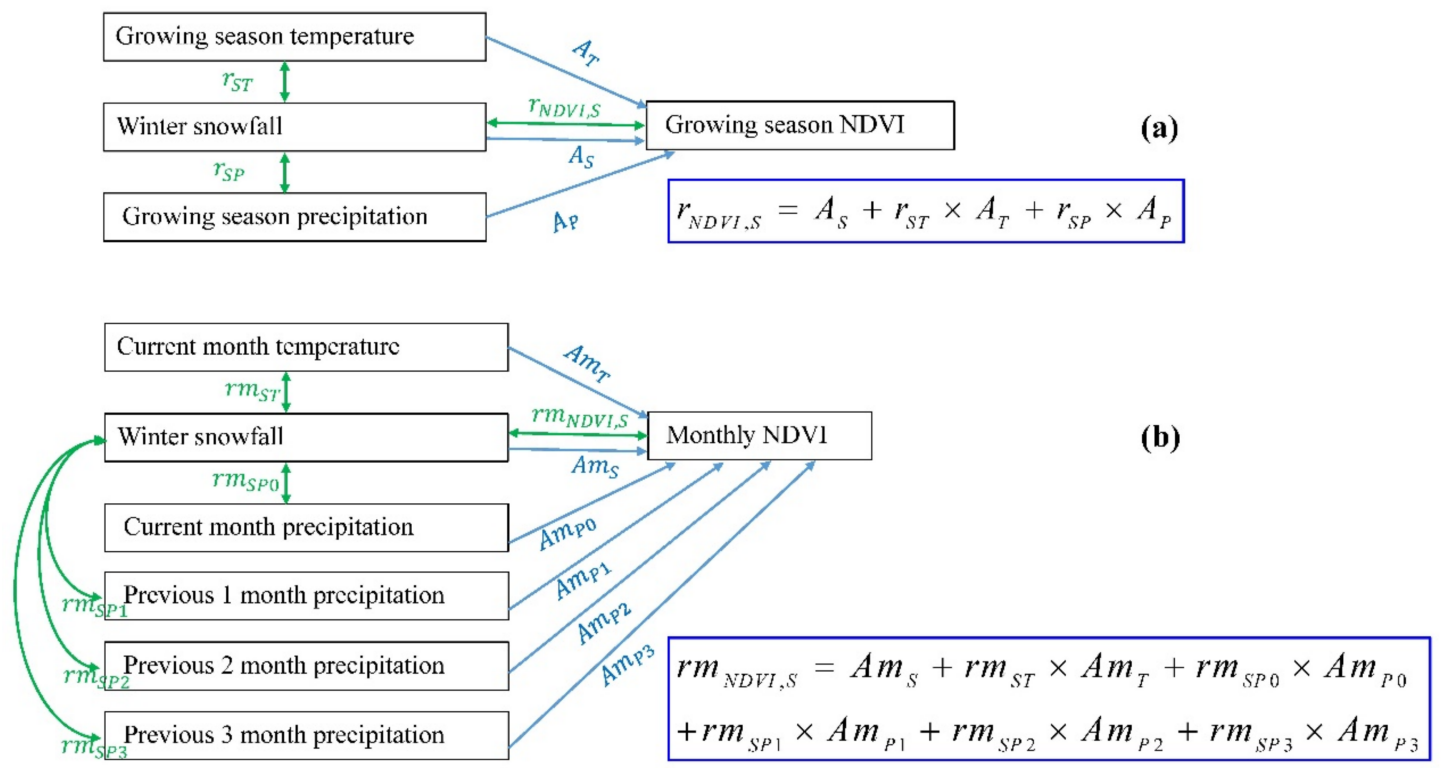

Figure 3. Path coefficient diagrams for growing season (a) and monthly (b) NDVI. $A$ and $r$ represent the direct path coefficient and Pearson correlation efficient, respectively. $m$ represents parameters for monthly variables. $S, T$, and $P$ represent winter snowfall, temperature, and precipitation, respectively. The subscripts $P 1-P 3$ indicate precipitation in the previous 1-3 months, and subscript $P 0$ indicates precipitation in the current month.

The percentage of winter snowfall direct effect to the Pearson correlation coefficient between winter snowfall and NDVI was used to represent the impact extent of snowfall direct effect on vegetation growth, while the percentage of indirect effect via temperature (precipitation) indicates the impact extent of interaction between snowfall and temperature (precipitation).

\subsubsection{Climatic Factor Importance to Vegetation Growth}

In this work, the variable importance in project (i.e., VIP) from the partial leastsquares regression (PLSR) was used to demonstrate the importance of winter snowfall, growing season precipitation, and temperature to vegetation growth. It is because that VIP retrieved from the PLSR can be utilized to describe the influence of independent variables on the dependent variables, and PLSR can handle partly or highly correlated variables [61,62]. Actually, there are complex correlations between climatic variables. For example, global warming decreased precipitation in North China and precipitation would decrease temperature $[63,64]$. In general, the independent variables with VIP larger than 1.0 are "important" to the dependent variables, while those with VIP less than 0.5 are "unimportant" to the dependent variables. Moreover, if VIP of an independent variable ranges from 0.5 to 1.0 , the importance level of this independent variable depends on the value of VIP [61,62], which is termed as "relatively important" in this study. 


\section{Results}

\subsection{Spatiotemporal Variation of NDVI during the Growing Season}

The spatial distributions of multi-year average NDVI in the growing season (i.e., from April to September) and each month were found to be similar (Figure 4). NDVI in Xinjiang is high in the Altai Mountains, North Slope of Tianshan Mountains, Ili Valley, and oases around the Taklimakan desert, while it is low in Junggar Basin, Tarim Basin, and Kunlun Mountains. NDVI in Kazakhstan moves downward from the north to the south, except the mountainous area in the east margins and cropland in the south where NDVI is high. NDVI in Kyrgyzstan and Tajikistan is high in the west while low in the east high mountains. In addition, NDVI in Turkmenistan and Uzbekistan is high in the east and cropland, while it is low in the west desert.

The variations of NDVI from 1982 to 2015 were different in each month (Figure 5). In April and May, NDVI variations were dominated by increase (including increase and increase significantly in Figure 5) with area percentages of $51 \%$ and $53 \%$ respectively, while those in other months by decrease (including decrease and decrease significantly in Figure 5) with area percentages greater than 55\%. The areas where NDVI increased significantly in April were mainly located in the west and north of Balkhash Lake, the plain around the Caspian Sea in Kazakhstan, North Central Turkmenistan, and the west and south periphery of Taklimakan desert, while those for May were mainly concentrated in Northeast Kazakhstan. In April and May, the NDVI of the whole area and each land cover type all increased. Particularly NDVI in cropland, forestland, grassland, and the whole study area all increased significantly in May at a rate not less than $0.008 /$ decade (Table 1 ). The percentage of decrease area (including decrease and decrease significantly in Figure 5) was relatively large in July and August, and the values were both $62 \%$. As a result, NDVI of the whole CA decreased in these two months (Table 1). In July and August, NDVI decreased significantly in the Junggar and Tarim Basin in Xinjiang, Ili delta, Turgay Plateau, and some areas in South Kazakhstan, as well as the southwest and southeast periphery of Aral Sea (Figure 5d,e).

Table 1. NDVI change trend for each land cover type and the whole region in April, May, June, July, August, September, and growing season (GS) from 1982 to 2015.

\begin{tabular}{cccccccc}
\hline /Decade & April & May & June & July & August & September & GS \\
\hline Farmland & 0.003 & $0.015^{*}$ & $0.011^{*}$ & 0.001 & 0.001 & 0.004 & 0.007 \\
\hline Forestland & 0.004 & $0.014^{*}$ & $0.007^{*}$ & 0.002 & 0.004 & 0.004 & 0.007 \\
\hline Grassland & 0.003 & $0.015^{*}$ & 0.006 & -0.003 & -0.001 & 0.002 & 0.006 \\
\hline $\begin{array}{c}\text { Sparse } \\
\text { vegetation }\end{array}$ & 0.004 & 0.001 & -0.004 & $\begin{array}{c}-0.004 \\
*\end{array}$ & $-0.004 *$ & -0.002 & -0.001 \\
\hline $\begin{array}{c}\text { Whole } \\
\text { Region }\end{array}$ & 0.004 & $0.008^{*}$ & -0.001 & -0.003 & -0.002 & 0.001 & 0.002 \\
\hline *
\end{tabular}

* indicates the NDVI change is significant at 0.05 level.

For the whole CA, the growing season NDVI decreased (including decrease and decrease significantly in Figure $5 \mathrm{~g}$ ) in 50\% of the region, while it increased (including increase and increase significantly in Figure $5 \mathrm{~g}$ ) in $48 \%$ of the region. The increased areas were mainly located in the Altai Mountains, Tianshan Mountains, and the oases in the west and north periphery of Taklimakan desert in Xinjiang, as well as East Kazakhstan, West Kyrgyzstan, and North Central Turkmenistan. The decreased areas were mainly located in West Kazakhstan, West Uzbekistan, South Turkmenistan, Junggar, and Tarim Basin in Xinjiang. Overall, the growing season NDVI in CA increased slightly at a rate of 0.002/decade from 1982 to 2015 (Table 1). Moreover, the growing season NDVI of cropland, forestland, and grassland all increased, while that of sparse vegetation decreased. 

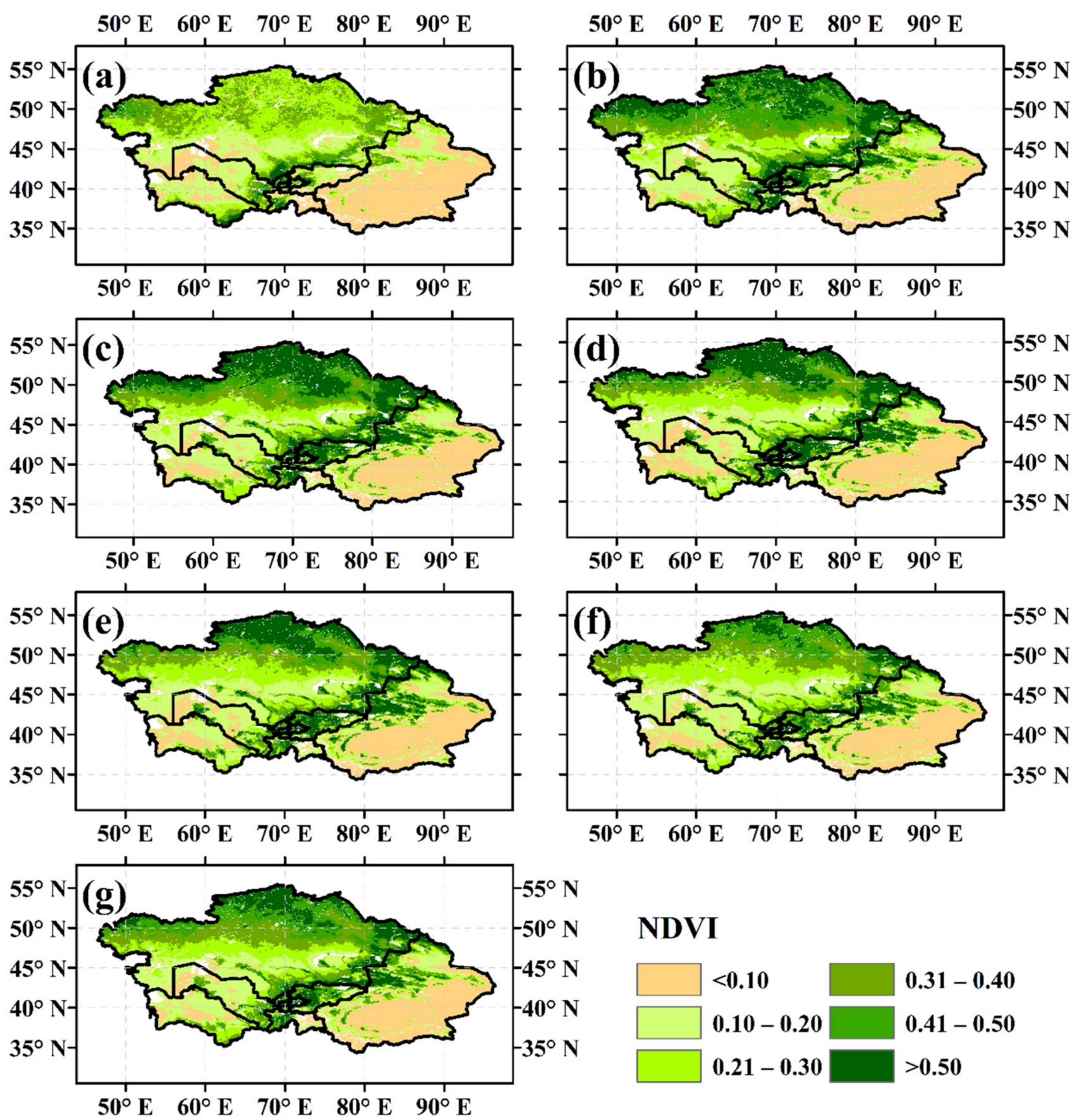

\section{NDVI}

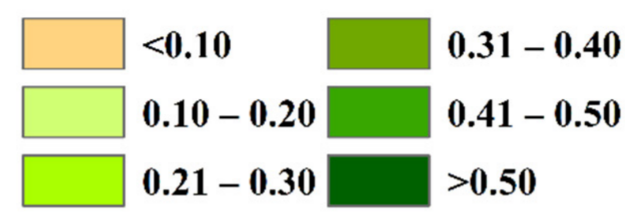

Figure 4. Multi-year mean NDVI from 1982 to 2015 in April (a), May (b), June (c), July (d), August (e), September (f), and growing season $(\mathrm{g})$. The blank area is water body, snow and ice, or urban area. 
$50^{\circ} \mathrm{E} \quad 60^{\circ} \mathrm{E} \quad 70^{\circ} \mathrm{E} \quad 80^{\circ} \mathrm{E} \quad 90^{\circ} \mathrm{E}$
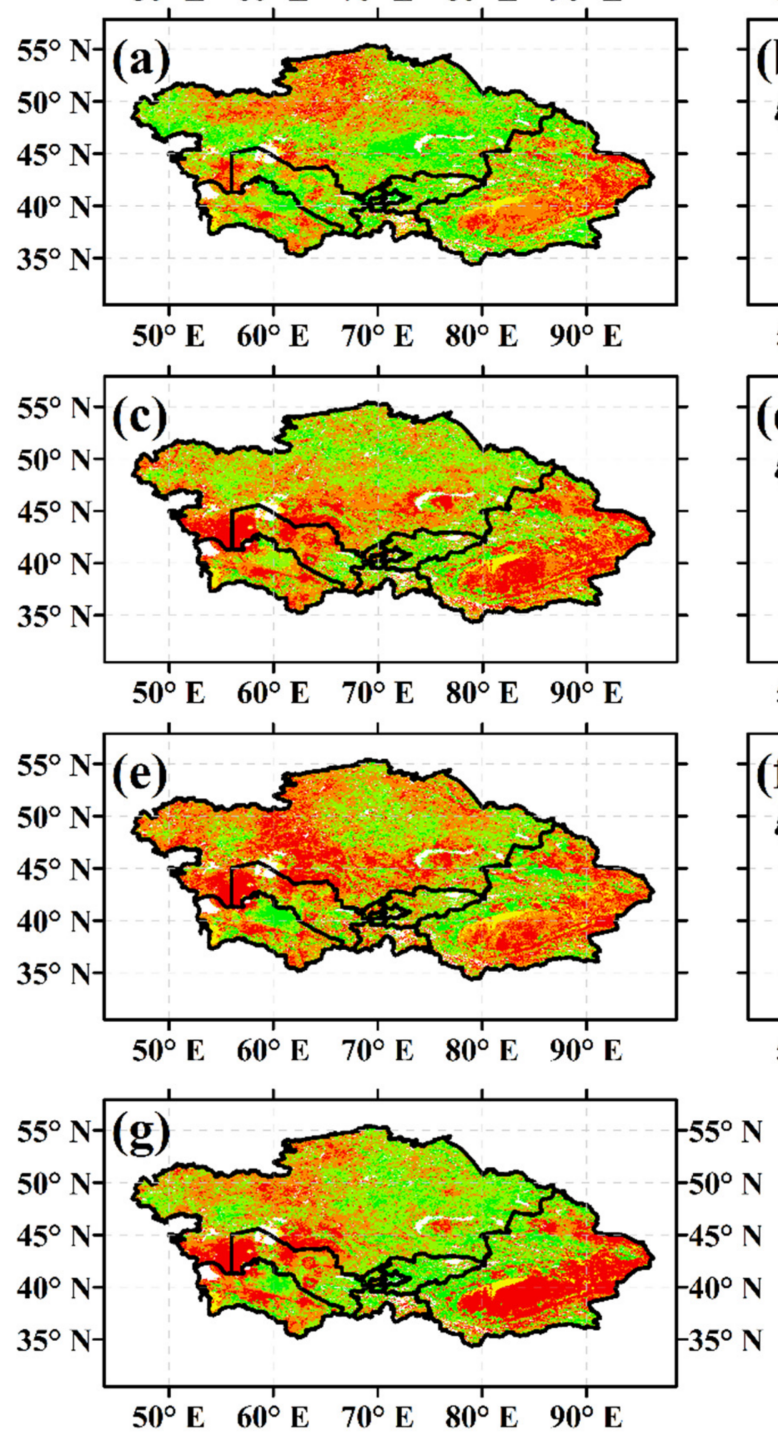

$\begin{array}{lllll}50^{\circ} \mathrm{E} & 60^{\circ} \mathrm{E} & 70^{\circ} \mathrm{E} & 80^{\circ} \mathrm{E} & 90^{\circ} \mathrm{E}\end{array}$
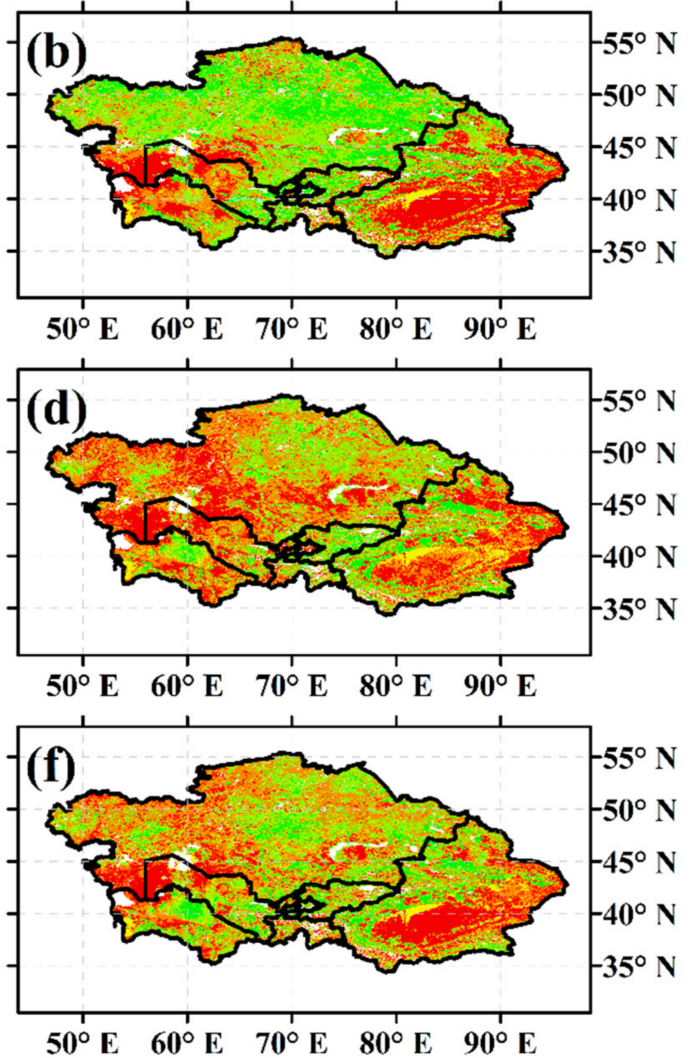

NDVI variation

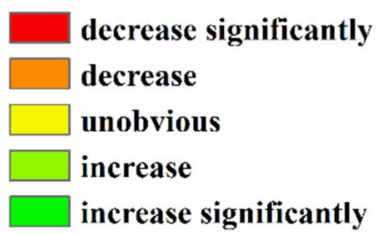

Figure 5. NDVI variation during 1982-2015 in April (a), May (b), June(c), July (d), August (e), September (f), and growing season $(\mathrm{g})$.

\subsection{Spatiotemporal Variation of Winter Snowfall}

Multi-year mean snowfall in each month of winter and the whole winter showed similar spatial patterns. The snowfall was high in the north and east edge of Kazakhstan, most parts of Kyrgyzstan and Tajikistan, as well as the Altai Mountains, Tianshan Mountains, Ili Valley, and the west section of Kunlun Mountains in Xinjiang (Figure 6). Area average winter snowfall of CA was about $33 \mathrm{~mm}$, and snowfall in December, January, and February were greater than that in March. Snowfall in forestland, grassland, and cropland was found to be greater than that in sparse vegetation.

Winter snowfall of all land-cover types and the whole CA generally showed an upward trend, and the increasing rates of forestland and grassland were larger than other land-cover types (Table 2). The increase (including increase and increase significantly in Figure 6j) of winter snowfall mainly occurred in the Kunlun Mountains, Tianshan Mountains, Altai Mountains, and Junggar Basin in Xinjiang, most areas of Kazakhstan, except the central parts and some areas in the northwest, most parts of Kyrgyzstan, and East Tajikistan. The area percentage of winter snowfall increase (including increase and increase significantly in Figure 6j) was about 50\%. Further, the area percentage of snowfall increase in February (51\%) was the largest among the winter months, and the second 
largest was in December (44\%). The winter snowfall decreased significantly in Central Kazakhstan and some areas in the west of Kyrgyzstan and Tajikistan. The area percentage of snowfall decrease (including decrease and decrease significantly in Figure 6) was the largest in January $(45 \%)$ among the winter months.

Table 2. Winter snowfall and its variation for each land-cover type and the whole region in 1982-2015.

\begin{tabular}{|c|c|c|c|c|c|}
\hline & Cropland & Forestland & Grassland & $\begin{array}{c}\text { Sparse } \\
\text { Vegetation }\end{array}$ & Whole Region \\
\hline Mean value (mm) & 50.75 & 52.86 & 49.89 & 19.16 & 32.98 \\
\hline Variation $\left(\mathrm{mm} \mathrm{a}^{-1}\right)$ & 0.04 & 0.14 & 0.14 & 0.01 & 0.09 \\
\hline
\end{tabular}
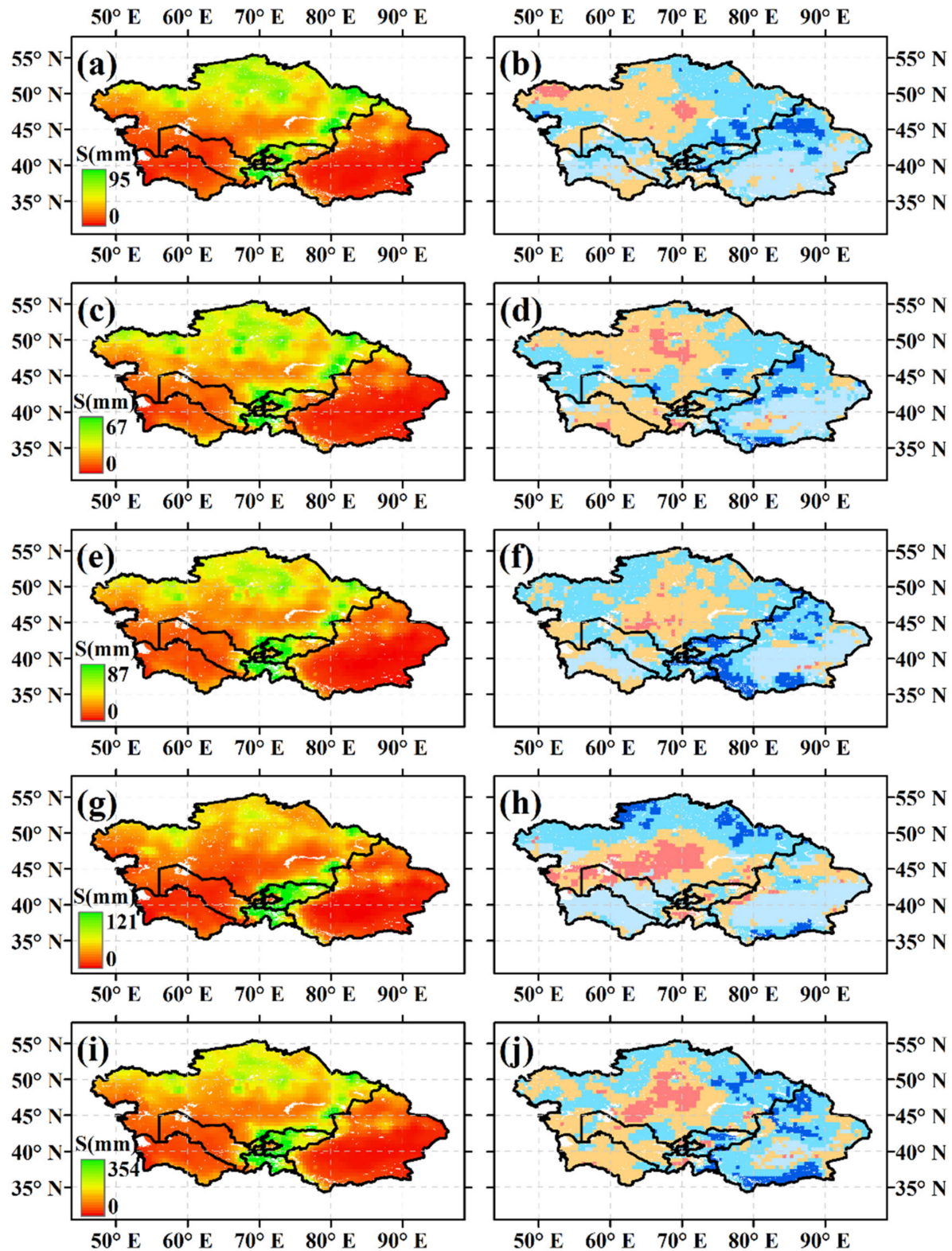

Snowfall variation

$\square$ decrease significantly $\square$ decrease $\square$ unobvious $\square$ increase $\square$ increase significantly

Figure 6. Multi-year mean snowfall and its variation in December (a,b), January (c,d), February (e,f), March (g,h), and winter $(\mathbf{i}, \mathbf{j})$. 


\subsection{Relationship between Vegetation Greenness and Winter Snowfall}

The Pearson correlation coefficient (i.e., $R$ ) between NDVI and winter snowfall was applied to show the response of vegetation greenness to winter snowfall. It was found that the correlation between growing season vegetation greenness and winter snowfall was positive $(R>0)$ in $64 \%$ of $C A$. Further, this positive vegetation response to winter snowfall was significant in $8 \%$ of the study area (positive $p<0.05$ and positive $p<0.01$ in Figure $7 \mathrm{~g}$ ). For example, the growing season vegetation greenness responded significantly and positively to winter snowfall in some areas of West and East Kazakhstan, North Xinjiang, and some areas around the Tarim basin (Figure 7g). Nevertheless, there are areas where growing season vegetation greenness still responded negatively and significantly to winter snowfall (negative $p<0.05$ and negative $p<0.01$ in Figure $7 \mathrm{~g}$ ). The areas are mainly located in the high mountains in Central and South Xinjiang, West Kyrgyzstan, and Tajikistan. The spatial distribution of correlation between monthly vegetation greenness and winter snowfall (Figure 7a-f) exhibited similarity with that between growing season vegetation greenness and winter snowfall, except for April. In April, there was a negative $(R<0)$ vegetation response to winter snowfall in $65 \%$ of $C A$ (Figure $7 \mathrm{a}$ ), and the correlation between vegetation greenness and winter snowfall was negative for the whole region.

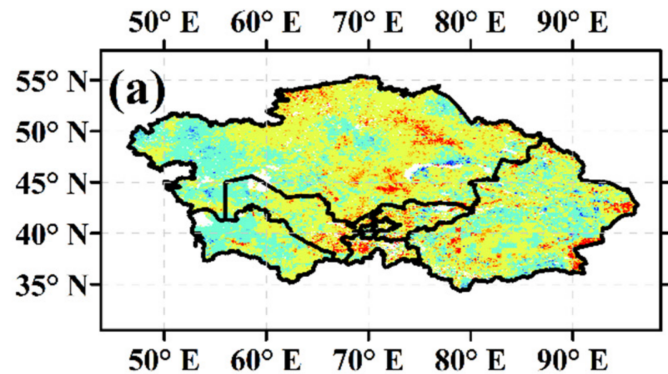

$50^{\circ} \mathrm{E} \quad 60^{\circ} \mathrm{E} \quad 70^{\circ} \mathrm{E} \quad 80^{\circ} \mathrm{E} \quad 90^{\circ} \mathrm{E}$
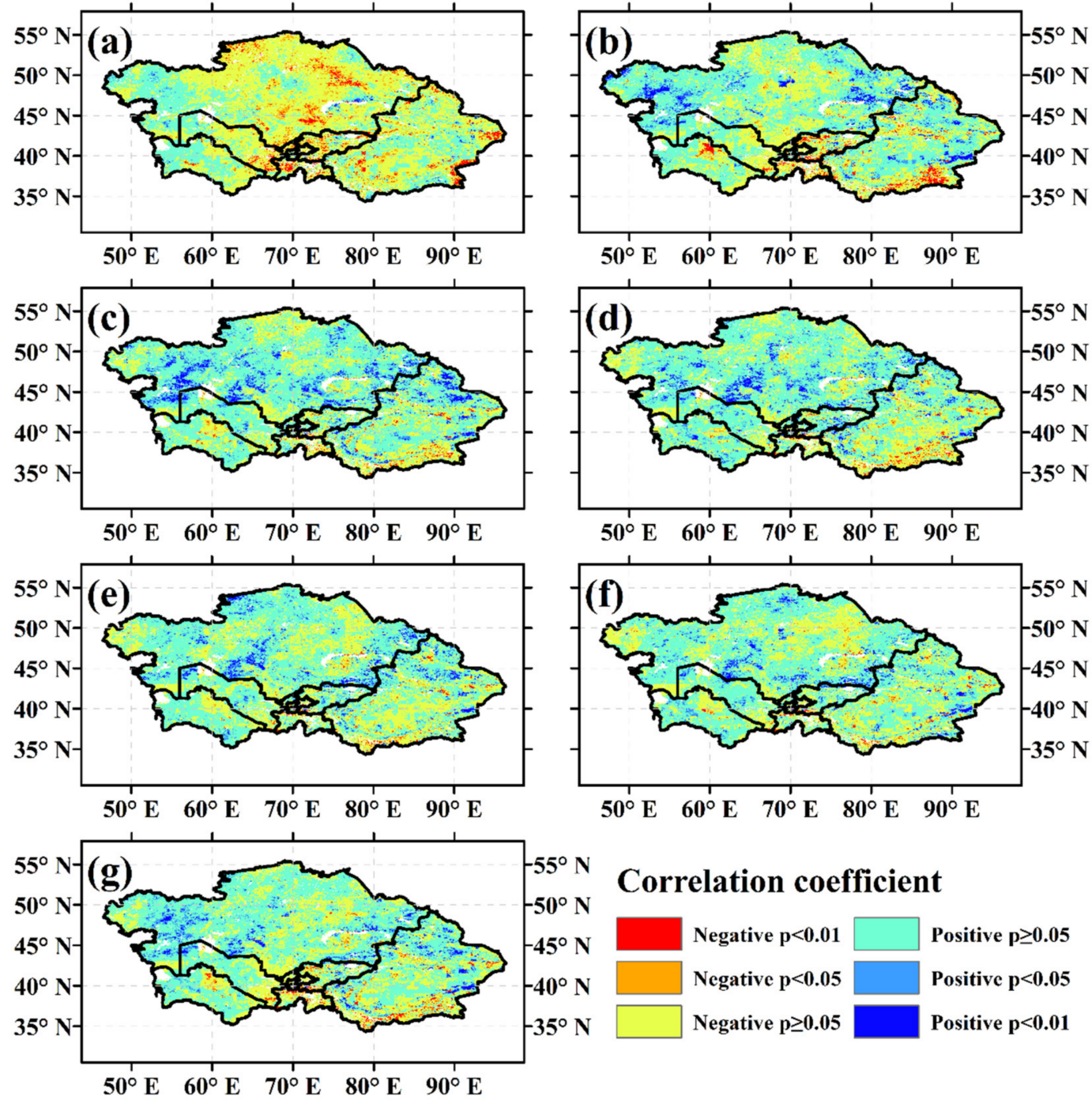

\section{Correlation coefficient}

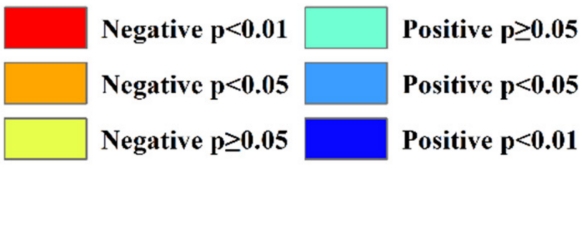

Figure 7. Correlation coefficient between winter snowfall and NDVI in April (a), May (b), June (c), July (d), August (e), September (f), and growing season $(\mathbf{g})$. 
In the growing season, as the month proceeds from April to September, the average Person correlation coefficients between winter snowfall and monthly NDVI of each land cover type and the whole region changed from negative to positive, then decreased slightly (Figure 8). It is noticed that the average correlation coefficient for grassland and sparse vegetation was negative in April, while that for the forestland and farmland was negative in April and May. As the month progresses, the maximum correlation coefficient for the former two land-cover types and the whole CA occurs in June, while that for the latter two land-cover types appears in August.

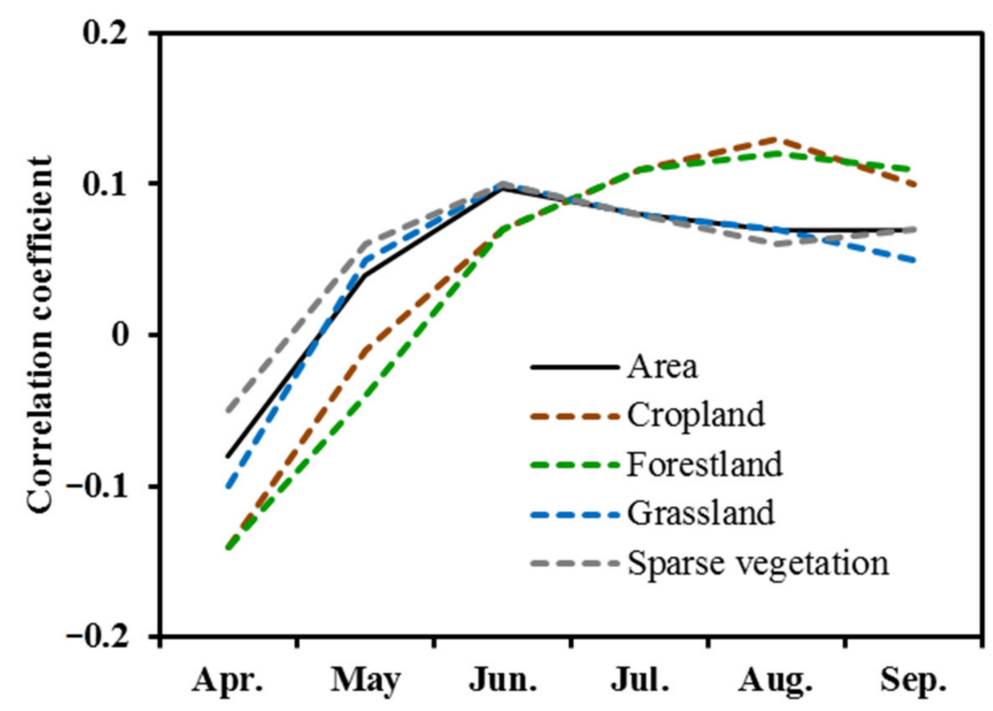

Figure 8. Average correlation coefficients between winter snowfall and monthly NDVI for different land-cover types and the whole study area.

\subsection{Direct Effect of Winter Snowfall and Its Interactions with Climatic Factors in the Growing Season}

Via the method described in Section 2.3.2, the extent and significance of winter snowfall's direct effect on vegetation greenness were examined for the whole growing season and each month, as well as the extent of the interaction between winter snowfall and temperature (precipitation) in the growing season. For the whole growing season (Figure 9a) and each month in the growing season, it was found that the vegetation greenness response to winter snowfall was dominated by its direct effect (the percentage of winter snowfall direct effect to the correlation coefficient between winter snowfall and NDVI greater than $51 \%$ ) in more than $70 \%$ of CA. However, the vegetation response to winter snowfall was dominated by its interaction with growing season temperature or precipitation in some areas. For example, the response of growing season vegetation greenness to winter snowfall was predominated by the interaction between winter snowfall and growing season precipitation in some areas of North Kazakhstan (Figure 9d), while the response in April was predominated by the interaction between winter snowfall and April temperature in the center of Kazakhstan and Altai mountains in Xinjiang, and the response in September was predominated by the interaction between winter snowfall and precipitation in the previous 1-2 months in some areas of North Kazakhstan. Additionally, except for some areas of North Kazakhstan in April and July, the interaction between winter snowfall and concurrent precipitation was negligible. Similar to the correlation between monthly vegetation greenness and winter snowfall (Figure 8), the area percentage of significant $(p<0.05)$ winter snowfall direct effect rose from April to June, then decreased afterward. The areas with significant winter snowfall direct effect on growing season greenness were mainly located in the North Xinjiang, the periphery of Taklimakan desert, and some areas in south Kazakhstan, Tajikistan, and Kyrgyzstan (Figure 9b). 

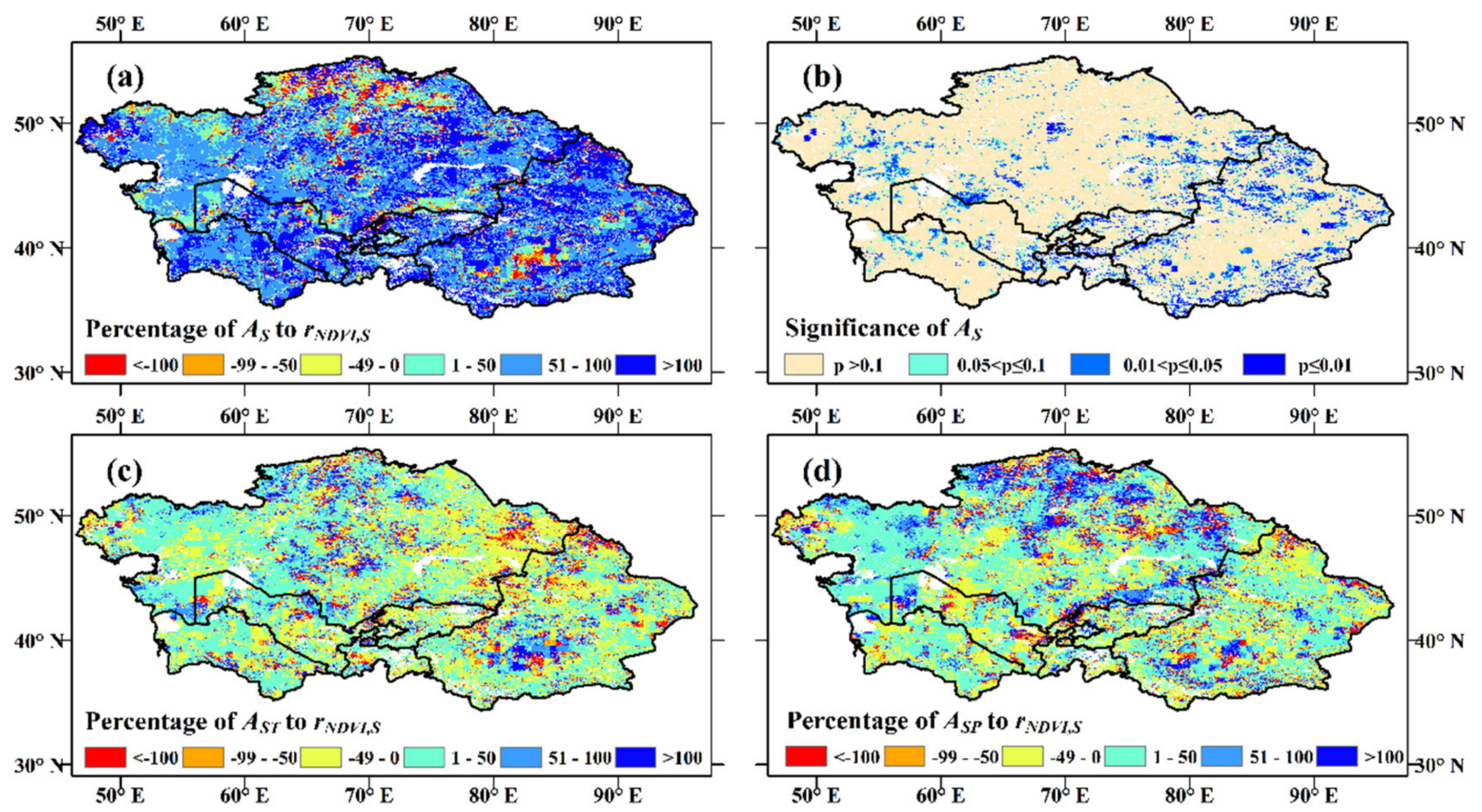

Figure 9. Extent $(\mathbf{a})$ and significance $(\mathbf{b})$ of the direct effect of winter snowfall $\left(A_{S}\right)$ on growing season vegetation greenness, the extent $(\mathbf{c})$ of the indirect effect of winter snowfall via the growing season temperature $\left(A_{S T}\right)$, and extent $(\mathbf{d})$ of the indirect effect of winter snowfall via growing season precipitation $\left(A_{S P}\right) . r_{N D V I, S}$ represents the correlated coefficient between winter snowfall and growing season NDVI.

\subsection{Importacne of Winter Snowfall and Climatic Factors in the Growing Season to Vegetation Greenness}

In order to identify the importance of winter snowfall's impact on vegetation growth, the importance of winter snowfall, growing season temperature, and growing season precipitation to growing season NDVI was compared by VIP obtained with PLSR (Figure 10). The results demonstrated that for the whole CA, the areas where winter snowfall was important to vegetation growth took up $41 \%$ of the region, while those for growing season temperature and precipitation accounted for $34 \%$ and $65 \%$, respectively. In some areas of East, South, and Central Kazakhstan, Central Uzbekistan, West Kyrgyzstan, East Tajikistan, Junggar basin, West Kunlun Mountain, and Tarim basin, as well as most parts of Turkmenistan, winter snowfall was important to vegetation growth. 

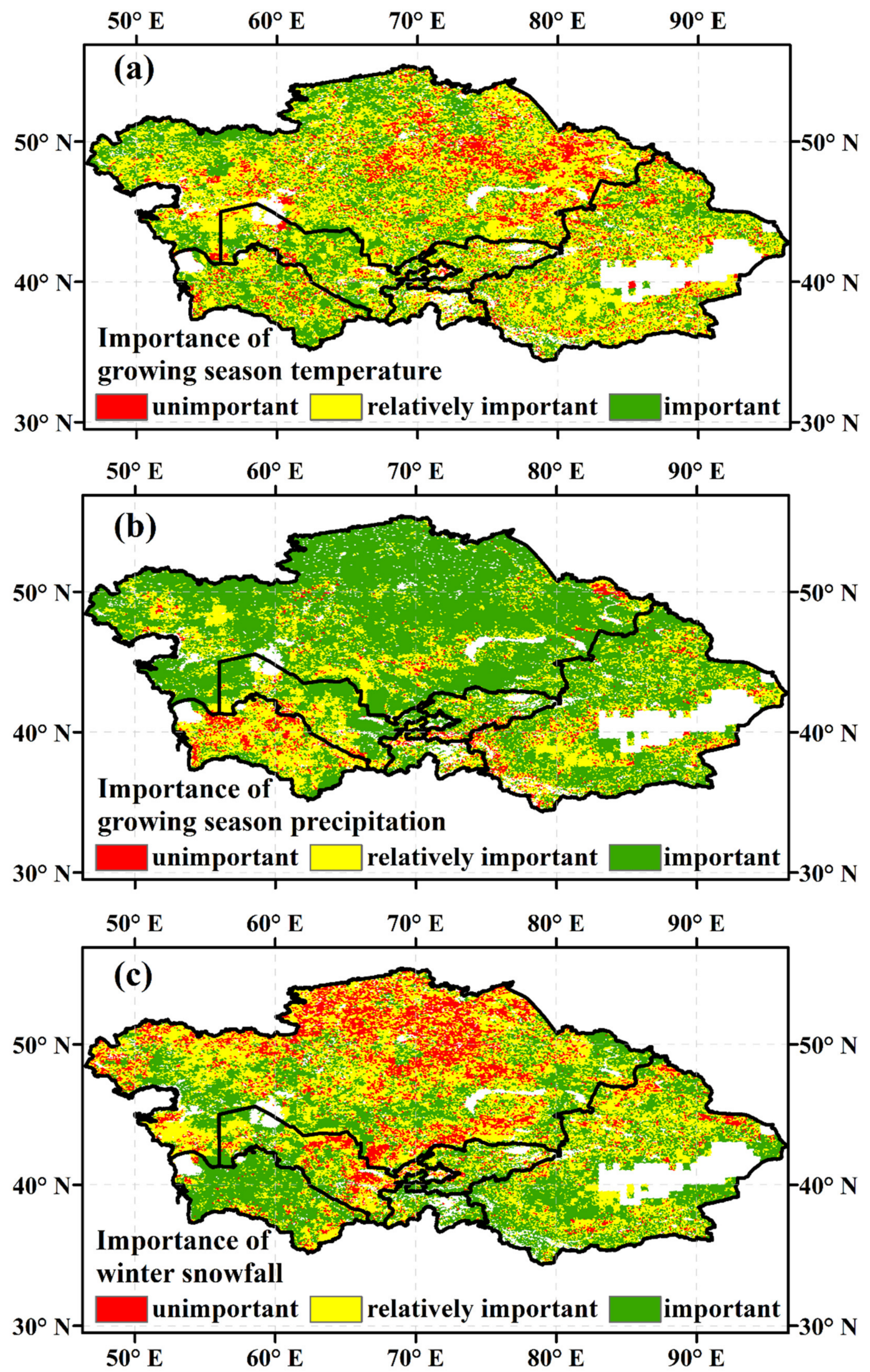

Figure 10. Importance of growing season temperature (a), precipitation (b), and winter snowfall (c) to vegetation growth for the period 1982-2015. 


\section{Discussion}

\subsection{Vegetation Response to Winter Snowfall}

Based on the results of this study and those reported by Zhang [32], the vegetation greenness in the growing season generally showed an upward trend from 1980s to 2010s in CA. The increase in vegetation greenness mainly occurred in the early growth stage or spring, which was consistent with the result in the five countries of CA $[38,47,65]$. Further, the growing season vegetation greenness increase area in CA was mainly located in the mountainous or hilly area, which agreed with previous studies $[32,47,66]$, although the linear regression and correlation coefficient were used to obtain the variation and its significance in this research. On the other hand, due to snowfall extreme increase under global warming, the winter snowfall increase in most parts of the Tianshan Mountains and in the northern part of Xinjiang (Figure 6j) agreed with previous reports [2,12,40,67]. The areas where winter snowfall decreases were mainly located at low altitudes in the five countries in CA, which related to the total winter precipitation decrease in recent decades [38].

There was a positive correlation between growing season vegetation greenness and winter snowfall in more than $60 \%$ of CA (Figure $7 \mathrm{~g}$ ). This is because snowmelt water can provide an important contribution to spring and summer soil moisture and, in turn, the vegetation growth $[68,69]$. This positive linkage in most parts of CA also occurred in each month of the growing season, except April (Figure 7a-f). The temperature is the main limiting factor of vegetation activity in the early growth stage in CA [65,66], and snow will create a cooler climate due to its high albedo [70]. Based on these two phenomena, it is inferred that when the winter snowfall increases, the temperature in the early vegetation growth stage may decrease, leading to a negative correlation between winter snowfall and vegetation activity in the early growth stage (such as April). Based on our estimations, the regional average correlation between winter snowfall and April temperature was negative, which verified the inference above to a certain extent.

Vegetation response to winter snowfall relates to land cover types in CA. For example, compared with forestland, the correlation between winter snowfall and grassland vegetation greenness in June is stronger, while it is weaker in August. Soil moisture plays a key role in vegetation growth in CA $[31,39]$. The root of grass is generally smaller and shallower than that of the forest, which can hold and uptake more deep soil water than grasses [65]. As a result, the grass is more sensitive to water than forest [33,37], and most of the soil moisture due to more snow utilized by grass until June [71].

\subsection{Effect of Winter Snowfall on Vegetation}

Based on the result of path analysis, the vegetation response to winter snowfall was mainly dominated by the direct effect of winter snowfall for the entirety of CA. In other words, the effect of winter snowfall on vegetation is scarcely regulated by temperature or precipitation in the growing season. However, the vegetation response to winter snowfall is interactively regulated by the growing season precipitation in some areas of north Kazakhstan. It is probably because summer precipitation is critical to vegetation growth [38]. In addition, the winter snowfall decreased significantly in central Kazakhstan, and the temperature in April closely correlated with winter snowfall in this area. As a result, the response of vegetation greenness in April to winter snowfall is regulated by concurrent temperature.

To further understand the effect of winter snowfall on vegetation growth, we examined the relationship between the total effect of winter snowfall (the correlation between winter snowfall and growing season vegetation greenness) and elevation. The results showed that the winter snowfall increase is mostly beneficial to vegetation growth when the elevation is low (below $3000 \mathrm{~m}$ ), contrary to when the elevation is high (above $3000 \mathrm{~m}$ ) (Figure 11a). The dominant negative effect at high elevation could be accredited to the possibility that more snow resulted from snowfall increase is expected to delay the date of snowmelt and spring onset and then suppress plant growth [72,73]. In contrast, the dominant positive effect at low elevation could be explained by the surplus moisture due to 
more snowfall promoting vegetation development, since the impact of water deficiency on vegetation greenness is more pronounced at low elevation [74]. Further, the magnitude of the positive effect of winter snowfall on vegetation growth decreased as elevation increased (Figure 11b). Considering that the impact of moisture on vegetation greenness decreases with increasing elevation [75], vegetation growth will become less sensitive to winter snowfall as elevation increases.
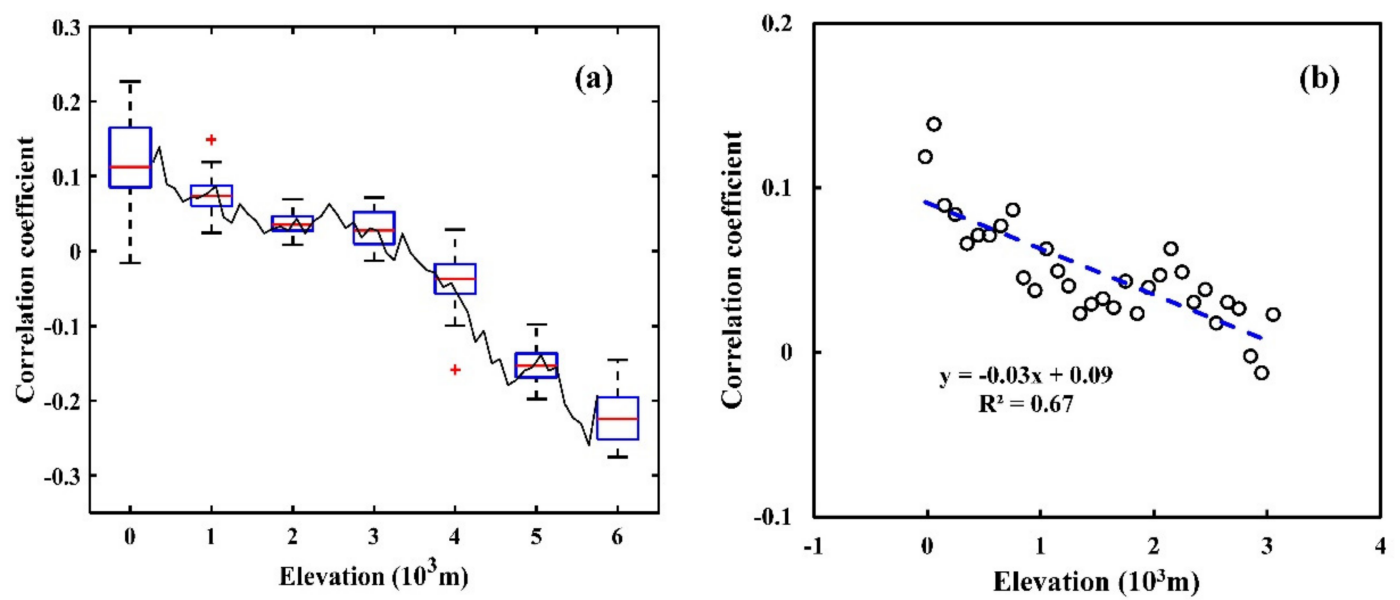

Figure 11. Correlation between winter snowfall and growing season vegetation greenness across the elevation below $6000 \mathrm{~m} \mathrm{(a)}$ and $3000 \mathrm{~m} \mathrm{(b)}$ for the period 1982-2015. The red plus represents the outlier, namely the data point which is greater than $q_{3}+1.5 \times\left(q_{3}-q_{1}\right)$ or less than $q_{1}-1.5 \times\left(q_{3}-q_{1}\right) \cdot q_{1}$ and $q_{3}$ are the 25 th and 75 th percentiles of the sample data, respectively.

Hydrothermal variables in the growing season are important to vegetation growth in CA $[47,66]$. Overall, winter snowfall is less important to vegetation growth than growing season precipitation for the whole CA, but more important than growing season temperature (Figure 10). Considering that water is the main limiting factor of vegetation growth in CA $[32,37]$ and the sensitivity of vegetation to temperature weakened in the Northern Hemisphere in recent decades [76], that the growing season temperature in CA is the least important is reasonable. Winter snowfall is the most important in some areas of south Kazakhstan, central Uzbekistan, west Kyrgyzstan, and most parts of Turkmenistan and Tajikistan, where the annual precipitation is less and not concentrated in the growing season [19]. Precipitation is mainly concentrated in the growing season in Xinjiang [77], but there are still some areas where winter snowfall is more important to vegetation growth than growing season precipitation, such as some areas in the center of Junggar Basin. The reason may be that the relative change of winter snowfall is greater. As shown in Figure 6i,j, winter snowfall was small in the center of Junggar Basin, while winter snowfall increased significantly in some areas.

\subsection{Uncertainties and Perspectives}

The ERA reanalysis data were used to explore the effect of climatic factors on vegetation growth in this study, while other climatic datasets were also used in CA, such as monthly temperature and precipitation of Climate Research Unit (CRU) or interpolated data based on stations' materials. It was found that the variations of climatic factors for the whole region might be consistent across different climatic datasets, while the spatial patterns of these variations might not $[36,37,65]$. The reanalysis data used in this study may induce uncertainties to the effect of climatic factors on vegetation to some extent. The ESA $\mathrm{CCI}$ land cover data were used to explore the vegetation greenness for different land cover types in the present study. Although the overall accuracy of ESA CCI land-cover product reaches $73 \%$ globally [78], there are still discrepancies between this land-cover product and the local land-cover product. For example, there is forestland in the east of Kunlun 
Mountains in Xinjiang based on ESA CCI land-cover data, while there is not based on the Vegetation Atlas of China [79]. This discrepancy will result in some uncertainties about vegetation response to winter snowfall of each land-cover type. In addition, considering that there is still vegetation in the deserts of CA [38], this study also examined the effect of winter snowfall on sparse vegetation located in the desert. However, the impact of soil background on the remote-sensing NDVI in the sparse vegetation area cannot be neglected [80], as it can trigger uncertainties to the result about sparse vegetation. The uncertainties above need to be evaluated further.

The spatial resolution of NDVI used in this study was $8 \mathrm{~km}$, which is suitable to explore the spatial variations of vegetation greenness in CA with such a large area, but not sufficient to represent the local variations of vegetation dynamics [81]. The local topographical conditions have an obvious impact on the vegetation greenness. For example, the south slope in the Ili valley in Xinjiang is predominated by grassland with relatively low greenness, while the northern slope is predominated by forestland with relatively high greenness [82]. The impact of local topography on vegetation needs to be explored in the future with finer remote-sensing products of high quality.

According to previous reports $[31,32,39,47,83]$, vegetation dynamics were different before and after the 1990s in CA. Namely, the vegetation greenness showed an upward trend before 1990s and downward after that. The reason behind was complex, which involved the natural and anthropic factors (such as the USSR Collapse). The trend analysis during multiple nested times series may contribute to a deep understanding of vegetation dynamics and the mechanism behind [66]. In the future, the vegetation response to both natural and anthropic factors requires further exploration with multiple nested times series.

\section{Conclusions}

Considering the winter snowfall as critical climatic and hydrological variables in $\mathrm{CA}$, the identification of the characteristics and mechanisms of vegetation response to winter snowfall in CA is critical for understanding the terrestrial ecosystem response to climate change. In this study, the vegetation response to winter snowfall was examined with Pearson correlation coefficient based on the ERA reanalysis climatic data and GIMMS NDVI data. Furthermore, the path analysis was used to decompose the correlation between winter snowfall and vegetation greenness into the direct effect of winter snowfall and the indirect effect of winter snowfall via temperature (precipitation) in the growing season to disentangle the impact path of winter snowfall on vegetation greenness.

The increase of winter snowfall is generally beneficial for the growing season vegetation greenness during 1982-2015, particularly in North Xinjiang and some areas of west and east Kazakhstan. However, winter snowfall increase is not beneficial for the vegetation greenness in April, since more snowfall will induce cooler climate in the early growing season. As the month progresses from April to September, the impact of winter snowfall on vegetation greenness rose from negative to positive, then reached its climax, and finally decreased slightly. The climax in grassland occurred in June, while that in forestland occurred in August, which relates to grass being more sensitive to water than forest. As the elevation is below $3000 \mathrm{~m}$, the surplus moisture due to more snowfall promotes vegetation development. However, when the elevation is above $3000 \mathrm{~m}$, more snowfall delays the onset of spring and suppresses plant growth.

The impact of winter snowfall on vegetation greenness is dominated by its direct effect for the whole region. The direct effect of winter snowfall is particularly important in North Xinjiang, the areas around Taklimakan desert in Xinjiang, and some areas in the east of five countries in CA. In North Kazakhstan, the precipitation mainly concentrates on the growing season, and the indirect effect of winter snowfall via growing season precipitation dominates the impact of winter snowfall on vegetation growth. In central Kazakhstan, the temperature in April relates to winter snowfall closely, and the indirect effect of winter snowfall via April temperature dominated the impact of winter snowfall on vegetation growth in April. For the whole growing season, winter snowfall is less important to 
vegetation growth than growing season precipitation, but more important than growing season temperature. However, winter snowfall is the most important in some areas where the relative increase of winter snowfall is greater or the rainy season does not concentrate on the growing season.

In future studies, there is a need to strengthen the spatial monitoring of vegetation dynamics in CA with finer remote-sensing vegetation data, land-cover data, and climatic data with high quality. Moreover, the multi-temporal vegetation response to natural and anthropogenic factors should be investigated with the data above and the socio-economic materials to better understand the ecosystem in arid regions and provide useful information for environmental protection in CA.

Author Contributions: F.H. carried out the study with the help from T.F. and wrote the draft with help from T.F., Z.G. and L.L. All authors have read and agreed to the published version of the manuscript.

Funding: This work is supported by the open project of the Xinjiang Uygur Autonomous Region Key Laboratory (2017D04010). The authors thank the NASA Global Inventory Modeling and Mapping Studies (GIMMS) group for producing and sharing the AVHRR GIMMS3g NDVI dataset.

Conflicts of Interest: The authors declare no conflict of interest.

\section{References}

1. Norin, L.; Devasthale, A.; L'Ecuyer, T.S. The sensitivity of snowfall to weather states over Sweden. Atmos. Meas. Tech. 2017, 10, 3249-3263. [CrossRef]

2. Qin, Y.; Ding, J. Change characteristics of different types of snowfall event in China's Tianshan Mountains from 1961 to 2016. Adv. Water Sci. 2019, 30, 457-466.

3. Blanchet, J.; Marty, C.; Lehning, M. Extreme value statistics of snowfall in the Swiss Alpine region. Water Resour. Res. 2009, 45, 12. [CrossRef]

4. Zhong, K.Y.; Zheng, F.L.; Zhang, X.C.; Qin, C.; Xu, X.M.; Lalic, B.; Cupina, B. Dynamic changes in snowfall extremes in the Songhua River Basin, Northeastern China. Int. J. Climatol. 2021, 41, 423-438. [CrossRef]

5. Ye, H.C.; Cho, H.R.; Gustafson, P.E. The changes in Russian winter snow accumulation during 1936-1983 and its spatial patterns. J. Clim. 1998, 11, 856-863. [CrossRef]

6. Qin, D.; Liu, S.; Li, P. Snow cover distribution, variability, and response to climate change in western China. J. Clim. 2006, 19, 1820-1833.

7. Heegaard, E. A model of alpine species distribution in relation to snowmelt time and altitude. J. Veg. Sci. 2002, 13, 493-504. [CrossRef]

8. $\mathrm{Wu}, \mathrm{Y}$;; Onipchenko, V.G. The impact of snow-cover on alpine vegetation type of different aspects in the west of Sichuan Province. Acta Ecol. Sin. 2007, 27, 5120-5129.

9. Gao, J.; Wang, J.N.; Xu, B.; Xie, Y.; He, J.D.; Wu, Y. Plant leaf traits, height and biomass partitioning in typical ephemerals under different levels of snow cover thickness in an alpine meadow. Chin. J. Plant Ecol. 2016, 40, 775-787.

10. Buus-Hinkler, J.; Hansen, B.U.; Tamstorf, M.P.; Pedersen, S.B. Snow-vegetation relations in a High Arctic ecosystem: Inter-annual variability inferred from new monitoring and modeling concepts. Remote Sens. Environ. 2006, 105, 237-247. [CrossRef]

11. Wipf, S. Phenology, growth, and fecundity of eight subarctic tundra species in response to snowmelt manipulations. Plant Ecol. 2010, 207, 53-66. [CrossRef]

12. Li, X.; Zhang, M.; Wang, B.; Wang, Y.; Wang, S. The Change Characteristics of Winter Snowfall, Snow Concentration Degree and Concentration Period in the Tianshan Mountains. Resour. Sci. 2012, 34, 1556-1564.

13. Lute, A.C.; Abatzoglou, J.T.; Hegewisch, K.C. Projected changes in snowfall extremes and interannual variability of snowfall in the western United States. Water Resour. Res. 2015, 51, 960-972. [CrossRef]

14. Davis, R.E.; Lowit, M.B.; Knappenberger, P.C.; Legates, D.R. A climatology of snowfall-temperature relationships in Canada. J. Geophys. Res. Atmos. 1999, 104, 11985-11994. [CrossRef]

15. Deng, H.; Chen, Y.; Chen, Z. Changes of Snowfall Under Warmer and Wetter in the Tianshan Mountains. Sci. Geogr. Sin. 2018, 38, 1933-1942.

16. Chen, X.; An, S.; Inouye, D.W.; Schwartz, M.D. Temperature and snowfall trigger alpine vegetation green-up on the world's roof. Glob. Chang. Biol. 2015, 21, 3635-3646. [CrossRef]

17. Yang, T.; Huang, F.R.; Li, Q.; Bai, L.; Li, L.H. Spatial-temporal variation of NDVI for growing season and its relationship with winter snowfall in Northern Xinjiang. Remote Sens. Technol. Appl. 2018, 32, 1132-1140.

18. Peng, S.; Piao, S.; Ciais, P.; Fang, J.; Wang, X. Change in winter snow depth and its impacts on vegetation in China. Glob. Chang. Biol. 2010, 16, 3004-3013. [CrossRef] 
19. Gessner, U.; Naeimi, V.; Klein, I.; Kuenzer, C.; Klein, D.; Dech, S. The relationship between precipitation anomalies and satellite-derived vegetation activity in Central Asia. Glob. Planet. Chang. 2013, 110, 74-87. [CrossRef]

20. Wan, Y.F.; Gao, Q.Z.; Li, Y.; Qin, X.B.; Ganjurjav; Zhang, W.N.; Ma, X.; Liu, S. Change of snow cover and its impact on alpine vegetation in the source regions of large rivers on the Qinghai-Tibetan Plateau, China. Arct. Antarct. Alp. Res. 2014, 46, 632-644. [CrossRef]

21. Mu, S.; Li, J.; Chen, Y.; Gang, C.; Zhou, W.; Ju, W. Spatial Differences of Variations of Vegetation Coverage in Inner Mongolia during 2001-2010. Acta Geogr. Sin. 2012, 67, 1255-1268.

22. Huang, F.R.; Mo, X.G.; Lin, Z.H.; Hu, S. Dynamics and responses of vegetation to climatic variations in Ziya-Daqing basins, China. Chin. Geogr. Sci. 2016, 26, 478-494. [CrossRef]

23. Chen, X. Retrieval and Analysis of Evapotranspiration in Central Areas of Asia; China Meteorological Press: Beijing, China, 2012.

24. Hu, Z.; Zhang, C.; Hu, Q.; Tian, H. Temperature Changes in Central Asia from 1979 to 2011 Based on Multiple Datasets. J. Clim. 2014, 27, 1143-1167. [CrossRef]

25. Hu, Z.; Zhou, Q.; Chen, X.; Qian, C.; Wang, S.; Li, J. Variations and changes of annual precipitation in Central Asia over the last century. Int. J. Climatol. 2017, 37, 157-170. [CrossRef]

26. Song, S.; Bai, J. Increasing Winter Precipitation over Arid Central Asia under Global Warming. Atmosphere 2016, 7, 139. [CrossRef]

27. Yang, H.; Xu, G.Y.; Mao, H.X.; Wang, Y. Spatiotemporal Variation in Precipitation and Water Vapor Transport Over Central Asia in Winter and Summer Under Global Warming. Front. Earth Sci. 2020, 8, 297. [CrossRef]

28. Li, J.; Zhang, S.; Pu, Z.; Wang, M.; Wang, S.; Zhao, S. Spatial-temporal variation of seasonal and annual air temperature in Xinjiang during 1961-2010. Arid Land Geogr. 2013, 36, 228-237.

29. Xu, T.; Shao, H.; Zhang, C. Temporal pattern analysis of air temperature change in Central Asia during 1980-2011. Arid Land Geogr. 2015, 38, 25-35.

30. Ma, Y.G.; Chen, X.; Niu, X.M.; Zhang, C. The trend and comparison of vegetation phenological change in Central Asia based GIMMS and SPOT Vegetation. Ecol. Environ. Sci. 2014, 23, 1889-1896.

31. Li, Z.; Chen, Y.; Li, W.; Deng, H.; Fang, G. Potential impacts of climate change on vegetation dynamics in Central Asia. J. Geophys. Res. Atmos. 2015, 120, 12345-12356. [CrossRef]

32. Zhang, Q.; Yuan, X.L.; Chen, X.; Luo, G.P.; Li, L.H. Vegetation change and its response to climate change in Central Asia from 1982 to 2012. Chin. J. Plant Ecol. 2016, 40,13-23.

33. Han, Q.; Luo, G.; Li, C.; Li, S. Response of carbon dynamics to climate change varied among different vegetation types in Central Asia. Sustainability 2018, 10, 3288. [CrossRef]

34. Bai, J.; Shi, H.; Yu, Q.; Xie, Z.; Li, L.; Luo, G.; Jin, N.; Li, J. Satellite-observed vegetation stability in response to changes in climate and total water storage in Central Asia. Sci. Total Environ. 2019, 659, 862-871. [CrossRef]

35. Mu, Z.X.; Jiang, H.F.; Liu, F. Spatial and temporal variations of snow cover area and NDVI in the west of Tianshan Mountains. J. Glaciol. Geocryol. 2010, 32, 875-882.

36. Dubovyk, O.; Landmann, T.; Dietz, A.; Menz, G. Quantifying the Impacts of Environmental Factors on Vegetation Dynamics over Climatic and Management Gradients of Central Asia. Remote Sens. 2016, 8, 600. [CrossRef]

37. Xu, H.; Wang, X.; Zhang, X. Decreased vegetation growth in response to summer drought in Central Asia from 2000 to 2012. Int. J. Appl. Earth Obs. Geoinf. 2016, 52, 390-402. [CrossRef]

38. Jiang, L.; Guli, J.; Bao, A.; Guo, H.; Ndayisaba, F. Vegetation dynamics and responses to climate change and human activities in Central Asia. Sci. Total Environ. 2017, 599-600, 967-980. [CrossRef] [PubMed]

39. Li, Y.; Chen, Y.; Sun, F.; Li, Z. Recent vegetation browning and its drivers on Tianshan Mountain, Central Asia. Ecol. Indic. 2021, 129, 107912. [CrossRef]

40. Wang, S.P.; Ding, Y.J.; Jiang, F.Q.; Anjum, M.N.; Iqbal, M. Defining Indices for the Extreme Snowfall Events and Analyzing their Trends in Northern Xinjiang, China. J. Meteorol. Soc. Jpn. 2017, 95, 287-299. [CrossRef]

41. Yang, T.; Li, Q.; Liu, W.; Liu, X.; Li, L.; De Maeyer, P. Spatiotemporal variability of snowfall and its concentration in northern Xinjiang, Northwest China. Theor. Appl. Climatol. 2020, 139, 1247-1259. [CrossRef]

42. Balashova, Y.N.; Zhitomirskaya, O.; Semyonova, O. Climatologic Characterization of the Central Asian Republics; Hydrometeorological Publishing House: Saint Petersburg, Russia, 1960. (In Russian)

43. Zhang, Y.; Jiang, F.; Wei, W.; Liu, M.; Wang, W.; Bai, L.; Li, X.; Wang, S. Changes in annual maximum number of consecutive dry and wet days during 1961-2008 in Xinjiang, China. Nat. Hazards Earth Syst. Sci. 2012, 12, 1353-1365. [CrossRef]

44. Pinzon, J.E.; Tucker, C.J. A Non-Stationary 1981-2012 AVHRR NDVI3g Time Series. Remote Sens. 2014, 6, 6929-6960. [CrossRef]

45. Fensholt, R.; Horion, S.; Tagesson, T.; Ehammer, A.; Ivits, E.; Rasmussen, K. Global-scale mapping of changes in ecosystem functioning from earth observation-based trends in total and recurrent vegetation. Glob. Ecol. Biogeogr. 2015, 24, $1003-1017$. [CrossRef]

46. Piao, S.; Mohammat, A.; Fang, J.; Cai, Q.; Feng, J. NDVI-based increase in growth of temperate grasslands and its responses to climate changes in China. Glob. Environ. Chang. Hum. Policy Dimens. 2006, 16, 340-348. [CrossRef]

47. Yin, G.; Hu, Z.; Chen, X.; Tiyip, T. Vegetation dynamics and its response to climate change in Central Asia. J. Arid Land 2016, 8, 375-388. [CrossRef] 
48. Weedon, G.P.; Gomes, S.S.; Viterbo, P.P.; Shuttleworth, W.J.; Blyth, E.E.; Österle, H.H.; Adam, J.C.; Bellouin, N.N.; Boucher, O.O.; Best, M.M. Creation of the WATCH Forcing Data and Its Use to Assess Global and Regional Reference Crop Evaporation over Land during the Twentieth Century. J. Hydrometeorol. 2011, 12, 823-848. [CrossRef]

49. Weedon, G.P.; Balsamo, G.; Bellouin, N.; Gomes, S.; Best, M.J.; Viterbo, P. The WFDEI meteorological forcing data set: WATCH Forcing Data methodology applied to ERA-Interim reanalysis data. Water Resour. Res. 2014, 50, 7505-7514. [CrossRef]

50. Fan, L.L.; Ma, J.; Wu, L.F.; Xu, G.Q.; Li, Y.; Tang, L.S. Response of the herbaceous layer to snow variability at the south margin of the Gurbantonggut Desert of China. Chin. J. Plant Ecol. 2012, 36, 126-135. [CrossRef]

51. Rigden, A.J.; Salvucci, G.D.; Entekhabi, D.; Gianotti, D.J.S. Partitioning Evapotranspiration Over the Continental United States Using Weather Station Data. Geophys. Res. Lett. 2018, 45, 9605-9613. [CrossRef]

52. Deng, Y.H.; Wang, S.J.; Bai, X.Y.; Luo, G.J.; Wu, L.H.; Chen, F.; Wang, J.F.; Li, C.J.; Yang, Y.J.; Hu, Z.Y.; et al. Vegetation greening intensified soil drying in some semi-arid and arid areas of the world. Agric. For. Meteorol. 2020, 292-293, 108103. [CrossRef]

53. Li, X.Y.; He, Y.; Zeng, Z.Z.; Lian, X.; Wang, X.H.; Du, M.Y.; Jia, G.S.; Li, Y.N.; Ma, Y.M.; Tang, Y.H.; et al. Spatiotemporal pattern of terrestrial evapotranspiration in China during the past thirty years. Agric. For. Meteorol. 2018, 259, 131-140. [CrossRef]

54. Meng, X.Y.; Gao, X.; Li, S.Y.; Lei, J.Q. Spatial and Temporal Characteristics of Vegetation NDVI Changes and the Driving Forces in Mongolia during 1982-2015. Remote Sens. 2020, 12, 603. [CrossRef]

55. Sun, W.C.; Wang, Y.Y.; Fu, Y.S.H.; Xue, B.L.; Wang, G.Q.; Yu, J.S.; Zuo, D.P.; Xu, Z.X. Spatial heterogeneity of changes in vegetation growth and their driving forces based on satellite observations of the Yarlung Zangbo River Basin in the Tibetan Plateau. J. Hydrol. 2019, 574, 324-332. [CrossRef]

56. Theil, H. A rank invariant method of linear and polynomial regression analysis: Part 3. Ned. Akad. Wetensch. Proc. 1950, 53, 1397-1412.

57. Sen, P.K. Estimates of regression coefficient based on Kendalls tau. J. Am. Stat. Assoc. 1968, 63, 1379-1389. [CrossRef]

58. Mann, H.B. Nonparametric tests against trend. Econometrica 1945, 13, 245-249. [CrossRef]

59. Kendall, M.G. Rank Correlation Methods; Charles Griffin: London, UK, 1975; p. 220.

60. Garcia del Moral, L.F.; Rharrabti, Y.; Villegas, D.; Royo, C. Evaluation of grain yield and its components in durum wheat under Mediterranean conditions: An ontogenic approach. Agron. J. 2003, 95, 266-274. [CrossRef]

61. Jia, J.S.; Deng, H.B.; Duan, J.; Zhao, J.Z. Analysis of the major drivers of the ecological footprint using the STIRPAT model and the PLS method-A case study in Henan Province, China. Ecol. Econ. 2009, 68, 2818-2824. [CrossRef]

62. Suo, L.; Huang, M.; Zhang, Y.; Duan, L.; Shan, Y. Soil moisture dynamics and dominant controls at different spatial scales over semiarid and semi-humid areas. J. Hydrol. 2018, 562, 635-647. [CrossRef]

63. Zhang, S.Q.; Ren, Z.Q.; Li, S.Q. The influence of fluctuation of global temperature on precipitation in China. Q. J. Appl. Meteorol. 1994, 5, 333-339.

64. Chuai, X.W.; Huang, X.J.; Wang, W.J.; Bao, G. NDVI, temperature and precipitation changes and their relationships with different vegetation types during 1998-2007 in Inner Mongolia, China. Int. J. Climatol. 2013, 33, 1696-1706. [CrossRef]

65. Propastin, P.A.; Kappas, M.; Muratova, N.R. Inter-Annual Changes in Vegetation Activities and Their Relationship to Temperature and Precipitation in Central Asia from 1982 to 2003. J. Environ. Inform. 2008, 12, 75-87. [CrossRef]

66. Du, J.; Shu, J.; Yin, J.; Yuan, X.; Jiaerheng, A.; Xiong, S.; He, P.; Liu, W. Analysis on spatio-temporal trends and drivers in vegetation growth during recent decades in Xinjiang, China. Int. J. Appl. Earth Obs. Geoinf. 2015, 38, 216-228. [CrossRef]

67. Zhuang, X.C.; Tian, Z.F.; Li, B.Y. Change of characteristic index of daily snowfall in winter in Altay prefecture, Xinjiang. Arid Zone Res. 2014, 31, 463-471.

68. Angert, A.; Biraud, S.; Bonfils, C.; Henning, C.C.; Buermann, W.; Pinzon, J.; Tucker, C.J.; Fung, I. Drier summers cancel out the $\mathrm{CO}_{2}$ uptake enhancement induced by warmer springs. Proc. Natl. Acad. Sci. USA 2005, 102, 10823-10827. [CrossRef]

69. Buermann, W.; Lintner, B.R.; Koven, C.D.; Angert, A.; Pinzon, J.E.; Tucker, C.J.; Fung, I.Y. The changing carbon cycle at Mauna Loa Observatory. Proc. Natl. Acad. Sci. USA 2007, 104, 4249-4254. [CrossRef]

70. Suzuki, K.; Hiyama, T.; Matsuo, K.; Ichii, K.; Iijima, Y.; Yamazaki, D. Accelerated continental-scale snowmelt and ecohydrological impacts in the four largest Siberian river basins in response to spring warming. Hydrol. Process. 2020, 34, 3867-3881. [CrossRef]

71. Li, P.; Sayer, E.J.; Jia, Z.; Liu, W.; Wu, Y.; Yang, S.; Wang, C.; Yang, L.; Chen, D.; Bai, Y.; et al. Deepened winter snow cover enhances net ecosystem exchange and stabilizes plant community composition and productivity in a temperate grassland. Glob. Chang. Biol. 2020, 26, 3015-3027. [CrossRef]

72. Wang, X.; Wang, T.; Guo, H.; Liu, D.; Zhao, Y.; Zhang, T.; Liu, Q.; Piao, S. Disentangling the mechanisms behind winter snow impact on vegetation activity in northern ecosystems. Glob. Chang. Biol. 2018, 24, 1651-1662. [CrossRef]

73. Wu, X.; Li, X.; Liu, H.; Ciais, P.; Li, Y.; Xu, C.; Babst, F.; Guo, W.; Hao, B.; Wang, P.; et al. Uneven winter snow influence on tree growth across temperate China. Glob. Chang. Biol. 2019, 25, 144-154. [CrossRef]

74. Wang, Y.; Fu, B.; Liu, Y.; Li, Y.; Feng, X.; Wang, S. Response of vegetation to drought in the Tibetan Plateau: Elevation differentiation and the dominant factors. Agric. For. Meteorol. 2021, 306, 108468. [CrossRef]

75. Rita, A.; Camarero, J.J.; Nolè, A.; Borghetti, M.; Brunetti, M.; Pergola, N.; Serio, C.; Vicente-Serrano, S.M.; Tramutoli, V.; Ripullone, F. The impact of drought spells on forests depends on site conditions: The case of 2017 summer heat wave in southern Europe. Glob. Chang. Biol. 2020, 26, 851-863. [CrossRef] 
76. Piao, S.; Nan, H.; Huntingford, C.; Ciais, P.; Friedlingstein, P.; Sitch, S.; Peng, S.; Ahlström, A.; Canadell, J.G.; Cong, N.; et al. Evidence for a weakening relationship between interannual temperature variability and northern vegetation activity. Nat. Commun. 2014, 5, 5018. [CrossRef]

77. Li, X.; Jiang, F.; Li, L.; Wang, G. Spatial and temporal variability of precipitation concentration index, concentration degree and concentration period in Xinjiang, China. Int. J. Climatol. 2011, 31, 1679-1693. [CrossRef]

78. Bontemps, S.; Defourny, P.; Van Bogaert, E.; Kalogirou, V.; Arino, O. GLOBCOVER: Products Description and Validation Report; UCL: Leuven, Belgium; ESA: Paris, France, 2011.

79. Editorial Committee for Vegetation Map of China. Vegetation Atlas of China; Science Press: Beijing, China, 2001.

80. Xu, X.R. Remote Sensing Physics; The Peking University Publishing House: Beijing, China, 2005; p. 176.

81. Wang, Z.X.; Suo, Y.X.; Lin, X.; Shi, R.X. Advances in AVHRR global time serials: PAL-GIMMS-LTDR. Resour. Sci. 2008, 30, 1252-1260.

82. Feng, T.; Huang, F.; Hao, J.; Li, L. Spatial distribution of surface soil moisture and soil conductivity in the Kunes Valley. Arid Zone Res. 2020, 37, 1457-1468.

83. Zhou, Y.; Zhang, L.; Fensholt, R.; Wang, K.; Vitkovskaya, I.; Tian, F. Climate Contributions to Vegetation Variations in Central Asian Drylands: Pre- and Post-USSR Collapse. Remote Sens. 2015, 7, 2449-2470. [CrossRef] 